\title{
The Effect of HIV/AIDS Education Prevention Using Web-Based She Smart on Knowledge, Attitudes, and Practice in Adolescent Girls
}

\author{
Komala Dewi Muslimin \\ Midwifery Studies Program, Graduate School of Hasanuddin University, Makassar, Indonesia
}

Corresponding author email: musliminkd19p@student.unhas.ac.id

\section{Yusring Sanusi Baso}

Learning Media Center, Learning Resource and E-Learning, Hasanuddin University, Makassar, Indonesia

Email: yusring@unhas.ac.id

\section{Healthy Hidayanty}

Department of Nutrition Sciences, Faculty of Public Health, Hasanuddin University, Makassar, Indonesia

Email: hhidayanty@yahoo.com

\section{Syafruddin Syarif}

Department of Electrical Engineering, Faculty of Engineering, Hasanuddin University, Makassar, Indonesia

Email: syafruddin.s@eng.unhas.ac.id

\author{
Aminuddin \\ Department of Nutrition, Faculty Of Medicine, Hasanuddin University, Makassar, Indonesia \\ Email: aminuddin@med.unhas.ac.id

\section{Burhanuddin Bahar} \\ Department of Nutrition Sciences, faculty Of Health, Hasanuddin University, Makassar, Indonesia \\ Email: baharburhanuddin96@gmail.com
}

\begin{abstract}
From year to year the number of cases of people with HIV/AIDS has increased. This increase is also experienced in Indonesia, where adolescents infected with HIV/AIDS show a number that tends to rise. It is characterized by a teenager's ignorance about reproductive health and knowledge of his sexual state. So many teenagers are at risk for early marriage problems, pregnancy, sexually transmitted infections, and also HIV/AIDS. To look at the influence of HIV/AIDS education on the knowledge, attitudes, and Practice of Adolescent girls. Use Pre-Experiment with one group pre-test and post-test design. Sampling technique using purposive sampling and obtained the number of 47 students. The research was conducted in Senior High School 12 Makassar in SeptemberOctober 2021. Data analysis using the McNemar Test. And statistical test results showed there was an influence on the use of HIV/AIDS education using web-based She Smart on knowledge where p-value =0,000, attitude with a value of $p$-value $=0.000$, and no significant difference in action with $p$-value $=0.500$. There is an influence on the use of web-based HIV/AIDS education using She Smart on knowledge and attitudes but no significant influence on actions before and after an intervention.

Keywords---adolescents, behavior, education, HIV/AIDS, knowledge.
\end{abstract}


Introduction

HIV (Human Immunodeficiency Virus) is a virus that attacks CD4 white blood cells so that it can weaken the human immune system. While AIDS is (Acquired Immune Deficiency Syndrome) is a collection of various symptoms of disease due to weakening of the immune system by the HIV (Green, 2016).

Adolescents infected with HIV / AIDS in Indonesia show this increasing number due to adolescent ignorance related to reproductive health. According to Makhitha \& Botha (2017), lack of education, communication, support, and information from teachers and also. Parents make teenagers do not understand the sexual problems faced when adolescence so that teenagers do not get an adequate understanding of their sexual health (Psacharopoulos, 1994).

Adolescence is a unique and critical period that a person has started from the age of 10-19 years Liang et al. (2019). During this time, there is a change from childhood to adulthood. During this transition, changes in adolescents include biological, psychological, and social changes (UNICEF, 2006). At times like this, teenagers must be given knowledge about sexuality to be their provision so as not to behave defiantly (Kamila \& Ismail, 2020).

HIV/AIDS is one of the diseases that continues to grow and become a global problem (Grulich et al., 2007). This is evidenced by data from UNAIDS in 2017 as many as 36.9 million and 18.2 million or $19 \%$ of them women aged 15-24 years living with HIV / AIDS. In 2018 as many as 37.9 million and 18.8 million or $20 \%$ of them women aged 15-24 years and in 2019 increased again as many as 38.0 million living with HIV / AIDS by 19.2 million or 19\% of them women aged 15-24 years (UNAIDS, 2019).

While data from the Indonesian Ministry of Health with the age group of 15-19 years for HIV positive 3.6\%, while for AIDS as much as $2.1 \%$ in 2017, HIV positive cases are $3.1 \%$ and for AIDS cases by $2.8 \%$ in 2018, then in 2019 HIV positive cases were obtained 2.9\% and in AIDS cases with 2.9\% (Indonesia Health Profile, 2019). And data from the South Sulawesi Provincial Health Office shows that the number of adolescents aged 15-19 years who had HIV / AIDS in 2015 with HIV cases as many as 163 people and 34 people with AIDS cases, in 2016 as many as 30 people with HIV cases and 16 people with AIDS cases, and in 2017 as many as 52 people with HIV and 5 people with AIDS cases (Depkes Sul-Sel, 2017).

The lack of knowledge of adolescents related to their sexual circumstances puts some adolescents at risk for problems of pregnancy outside of marriage, early marriage, sexually transmitted infections, and also HIV / AIDS. Therefore, correct information related to the problem is important to prevent the younger generation from being affected by information that can trigger risky behavior (Ardina, 2011).

Adolescent girls in Uganda showed almost all (99.3\%) said they had heard of HIV/AIDS, but only (48.1\%) had comprehensive knowledge (Estifanos et al., 2021). This is in line with Dzah et al (2019), research, which says that adolescents in Ghana generally have less knowledge related to HIV/AIDS, show negative attitudes towards HIV, and also engage in risky practices (Tarkang et al., 2019).

At times like today make the medium of communication technology that can be accessed anywhere and anytime has a fairly important impact on human life, one of which has an impact on teenagers who are difficult to escape from smartphone use (Sudiarto et al., 2019). Some studies say that the use of technology in the field of health can help a person to get health information quickly (Yani, 2018).

Looking at data from various research results in adolescents on the incidence of HIV/AIDS makes education is an important thing to do to avoid adolescents getting caught up in risky behaviors (Brener \& Collins, 1998; ZimmerGembeck et al., 1997). In addition, the importance of providing education can also help the development of adolescents without any problems caused by these problems (Robinson \& Sexton, 1994). Based on the description above, this study aims to look at the influence of HIV / AIDS education on the knowledge, attitudes, and Practice of Adolescent girls (De Cock et al., 2002).

\section{Research Methods}

This study uses the Pre-Experiment method with the design form used by one group of pre-test and post-test which is a way that researchers do to find out the state of the subject before and after treatment so that researchers can see the results of comparisons or see changes from the subject (Setiawan \& Prasetyo, 2015). Research instruments use questionnaires that have been tested for validity and reliability. This research was conducted at Senior High School 12 Makassar in September-October 2021 after getting ethical Clearance from the ethics committee of the Faculty of Public Health of the University Hasanuddin Makassar with number 7401/UN4.14.1/TP.01.02/2021.

The population in this study is all-female students class XI Senior High School 12 Makassar as many as 152 people. Sampling is done with purposive sampling. The sample in the study was obtained using Slovin's formula and obtained by 47 female students. Data collection techniques are performed using primary data and secondary data. Primary data are obtained directly from respondents using questionnaires. Secondary data was obtained from student 
documents. The variable in the study was an increase in knowledge, attitudes, and actions after treatment. Before being given the treatment respondents fill out the pre-test on the web first. The provision of education is carried out for four weeks, after which only fills the post-test with the duration of education twice per week. Data processing is done using SPSS through editing, coding, and tabulating. The data analysis in this study used the McNemar Test.

\section{Results and Discussion}

Table 1

The influence of HIV/AIDS education using web-based She Smart on Adolescent girl's knowledge

\begin{tabular}{|c|c|c|c|c|c|c|c|}
\hline \multirow{3}{*}{ Pre-Test } & \multicolumn{4}{|c|}{ Post-Test } & \multirow{2}{*}{\multicolumn{2}{|c|}{ Total }} & \multirow{3}{*}{$\mathrm{p}$} \\
\hline & \multicolumn{2}{|c|}{ Good } & \multicolumn{2}{|c|}{ Less } & & & \\
\hline & $\mathrm{n}$ & $\%$ & $\mathrm{n}$ & $\%$ & $\mathrm{n}$ & $\%$ & \\
\hline Less & 13 & 27,6 & 0 & 0 & 13 & 27,6 & \\
\hline Good & 33 & 70,2 & 1 & 2,2 & 34 & 72,4 & 0,000 \\
\hline Total & 46 & 97,9 & 1 & 2,2 & 47 & 100 & \\
\hline
\end{tabular}

Based on the results of table 1. Adolescents who experienced a change in knowledge from a lesser category to 13 people (27.6\%), a good category of less than 1 person (2.2). Then, students who have a good attitude before doing. The intervention did not change after intervention as many as 33 people $(70.2 \%)$. So the number of students who have a good attitude as many as 46 people (97.9\%) and who have less attitude as much as 1 a person $(2.2 \%)$. The value $\mathrm{p}$-value $=0.000(\mathrm{p}<0.05)$ means that statistically shows there is a significant difference in knowledge before and after education.

Table 2

The influence of HIV/AIDS education using web-based She Smart on the Adolescent girl's attitudes

\begin{tabular}{|c|c|c|c|c|c|c|c|}
\hline \multirow{3}{*}{ Pre-Test } & \multicolumn{4}{|c|}{ Post-Test } & \multirow{2}{*}{\multicolumn{2}{|c|}{ Total }} & \multirow{3}{*}{$\mathrm{p}$} \\
\hline & \multicolumn{2}{|c|}{ Good } & \multicolumn{2}{|c|}{ Less } & & & \\
\hline & $\mathrm{n}$ & $\%$ & $\mathrm{n}$ & $\%$ & $\mathrm{n}$ & $\%$ & \\
\hline Less & 5 & 10,6 & 1 & 2,2 & 6 & 12,8 & \\
\hline Good & 41 & 87,2 & 0 & 0 & 41 & 87,2 & 0,000 \\
\hline Total & 46 & 97,8 & 1 & 2,2 & 47 & 100 & \\
\hline
\end{tabular}

Based on table 2. They showed that after the intervention, adolescents who experienced a change in attitude from less to good category as many as 5 people $(10.6 \%)$, good category to less non-existent. Then, students who had a good attitude before the intervention and did not experience changes after intervention as many as 41 people $(87.2 \%)$. So the number of students who have a good attitude as many as 46 people (97.8\%) and who have less attitude as much as 1 a person $(2.2 \%)$. Based on the results of statistical tests obtained the value of $\mathrm{p}=0.000$ $(\mathrm{p}<0.05)$ shows there is a significant difference in attitude before and after education.

Table 3

The effect of providing HIV/AIDS education using web-based She Smart on the Adolescent girl's Practice

\begin{tabular}{|c|c|c|c|c|c|c|c|}
\hline \multirow{3}{*}{ Pre-Test } & \multicolumn{4}{|c|}{ Post-Test } & \multirow{2}{*}{\multicolumn{2}{|c|}{ Total }} & \multirow{3}{*}{$\mathrm{p}$} \\
\hline & \multicolumn{2}{|c|}{ Positive } & \multicolumn{2}{|c|}{ Negative } & & & \\
\hline & $\mathrm{n}$ & $\%$ & $\mathrm{n}$ & $\%$ & $\mathrm{n}$ & $\%$ & \\
\hline Negative & 2 & 4,3 & 0 & 0 & 2 & 4,3 & \\
\hline Positives & 45 & 95,7 & 0 & 0 & 45 & 95,7 & 0,500 \\
\hline Total & 47 & 100 & 0 & 0 & 47 & 100 & \\
\hline
\end{tabular}

Based on table 3. The results showed that after the intervention, there was no data that showed a change to negative action. The change in action occurred from negative to a positive category as many as 2 people (4.3\%) while positive action before intervention did not change as many as 47 people $(95.7 \%)$ with a value of $\mathrm{p}=0.500(\mathrm{p}>0.05)$. The statistics showed no significant harm before and after HIV/AIDS education in adolescent girls. 
The influence of the use of HIV/AIDS education model using Web-based She Smart on the knowledge of Adolescent girls

Providing HIV/AIDS education through web-based She Smart was able to increase awareness where as many as 47 respondents, 22 respondents had less knowledge before being given an education. But after providing education, less knowledgeable respondents entered the good increased by $46.8 \%$.

One of the factors that cause adolescents to be very susceptible to contracting HIV/AIDS because teenagers always want to know new things in the process of finding themselves (Blalock et al., 2002). This is a characteristic of teenagers in general. One of the preventive efforts of HIV/AIDS transmission is to increase the level of knowledge of vulnerable groups. Adolescents are one of the vulnerable groups because adolescents are in a transition from childhood to adulthood. In adolescence, there are not only physical changes but also psychological and social. Adolescent curiosity about something is very high, so often teenagers look for that information through the internet, parents, teachers, and peers.

This is also in line with Kamila and Ismail, (2020) research also showed a significant increase from the average pre-test results of 63.8 and post-test 89.4. This shows that effective counseling activities increase students' knowledge of Health Reproduction and HIV/AIDS ( $\mathrm{p}<0.05$ ). Research conducted at Mengwi State High School 2, also showed the same results, namely before counseling on HIV/AIDS student knowledge is 49.7 (Satriawibawa et al., 2018).

In the current of globalization, the dissemination of information, especially through the internet, can be quickly known by everyone, especially teenagers so teenagers often get wrong information about HIV/AIDS. Like to talk about problems or learn things with their peers rather than with someone who is or puts themselves in a position to advise or manage their lives. The provision of HIV/AIDS education using web-based She Smart can increase the knowledge of young women, this cannot be separated from the presentation of material on the web and also interesting animated videos that have been tested first.

By using various media in a variety of ways, it will have an impact on changing people's knowledge and attitudes regarding HIV/AIDS. Research conducted by Rahmawati (2020), which says education through interactive dialogue increases youth awareness about the importance of increasing knowledge related to the dangers of HIV/AIDS (Syed et al., 2013). Comprehensive knowledge about HIV can help women make choices about practices that can prevent them from getting HIV/AIDS (Nubed \& Akoachere, 2016). Correct knowledge is very influential in forming the right attitude and giving space for someone to think further about the decisions to be taken. Although knowledge is sufficient, it cannot guarantee that someone will not do risky activities.

The influence of the use of HIVIAIDS education model using Web-based She Smart on the attitudes of Adolescent girls

Efforts that can be done on the prevention of HIV/AIDS are to provide proper health education. This study showed that of 47 respondents as many as 16 respondents had less attitude before being given an education, then after being given education respondents who have less attitude increased to 15 people $(31.9 \%)$. Teenagers whose level of knowledge is good and then supported by the environment, family and peers will help teenagers better choose what is good and what is bad for them. The assessment of knowledge in the form of observation and experience is what will make up the attitude of each individual (Markolinda \& Sawirman, 2018).

There was one respondent who had a negative attitude before and after being given an education because of many factors that affect it, one of which is a personal experience, the influence of others, and also emotional factors so that the absorption of educational materials and videos is not acceptable maximal. The same results were shown by Kusnan et al. (2019), research, the attitude of State High School students 4 Kendari before counseling was obtained $11(20.4 \%)$ respondents showed a good attitude and after counseling, there was a significant influence, namely, 37 $(68.5 \%)$ respondents showed a good attitude.

Attitude is a person's reaction to the stimulation received to produce likes-dislike, agree-disagree, good-no thinking Well, and so on. A person's attitude negates them being ready or willing to act but has not shown any real action. Attitude is part of the predisposition of behavior (Notoatmodjo, 2010).

This is contrary to the research conducted by (Juliansyah, 2020). The title of the influence of HIV/AIDS counseling on students' knowledge and attitudes shows a value of p-value $=0.064$. The results of the statistical test using the T-test means statistically there is no significant difference in student attitude before and after counseling where the attitude of students before counseling is 92.25 changed to 93.82 after counseling. 
Someone who has enough knowledge will give a positive response or attitude to a problem because with enough knowledge someone can already understand the existing problem (Sambono, 2013). Therefore, education about HIV/AIDS should be provided comprehensively because of lack of knowledge or misinformation related to HIV/AIDS, and not getting justification will affect a person's attitude in the long term. Therefore, the provision of education related to HIV/AIDS must be provided comprehensively because a lack of knowledge or misinformation related to HIV/AIDS will affect a person's attitude in making decisions (Sarada \& Mallikarjuna, 2018).

The influence of the use of HIVIAIDS education model using Web-based She Smart on the Practice of Adolescent girls

Most Indonesians talk about sex to children as the opposite of culture. But on the other hand, the development of technology makes access to information very easy to get included things related to sexuality. But unfortunately, there are still many teenagers who have not received a complete sexual education so many of them are caught up in risky behaviors (Porges, 2003).

The formation of a new behavior begins from the cognitive part where the person must know in advance the stimulation in the form of knowledge to produce a new understanding of an object that has been known than the stimulation in the form of a new understanding will produce a further response in the form of a reaction (action) to the object. The stimulation received from the object can directly affect a person's actions. If the acceptance of new behavior or the adoption of behavior through such a process, which is based on knowledge, awareness, and a positive attitude then the behavior will be lasting (Kelley et al., 2003). So it can be concluded that although one's knowledge of an object is lacking if it is based on self-awareness and concern for HIV/AIDS prevention measures, there will be a positive attitude towards an object (Notoatmodjo, 2010).

The study showed that of 47 respondents, only two respondents acted less before education, and 45 respondents had actions both before and after being given an education. But after being given education respondents who has less action increased. It is also seen that almost all respondents already have good precautions before being given an education. This is by the above theory that says that although knowledge is lacking, based on self-awareness and concern not to engage in risky behavior, positive action will arise. The same was obtained by Hamdi et al. (2016), after the intervention of KIE ABAT in the single group obtained a value of $p=0.711$ which means there is no significant difference in preventive measures before and after an intervention. HIV/AIDS prevention efforts in adolescents are an important issue to note given the many behavioral problems adolescents are getting closer to susceptibility to HIV/AIDS. Adolescent behavior today tends to occur deviations in sexuality issues, as well as drug abuse.

One way that educational messages can influence people to act is through the selection of appropriate educational strategies. According to Yeow Chye and Angela Caires, the health promotion model focuses on individual characteristics and experiences, and behaviors of specific awareness and outcomes ( $\mathrm{Ng} \&$ Caires, 2016). Therefore, educational strategies are needed with methods that can adjust the situation and conditions so that the interventions carried out can be effective. This study has limitations where data collection is done with self-reports that demand the honesty of the subject, especially attitude variables and HIV/AIDS prevention measures.

\section{Conclusion}

HIV/AIDS education using web-based She Smart as a model for providing education can increase knowledge and attitudes, but in action, there is no significant increase.

\section{Acknowledgments}

Researchers thanked both parents and the Principal and teachers and the younger siblings of State High School student 12 Makassar.

\section{References}

Ardina, M. (2011). Communicate. Oncology in Clinical Practice 7.

Blalock, A. C., Mcdaniel, J. S., \& Farber, E. W. (2002). Effect of employment on quality of life and psychological functioning in patients with HIV/AIDS. Psychosomatics, 43(5), 400-404. https://doi.org/10.1176/appi.psy.43.5.400

Brener, N. D., \& Collins, J. L. (1998). Co-occurrence of health-risk behaviors among adolescents in the United States. Journal of adolescent health, 22(3), 209-213. https://doi.org/10.1016/S1054-139X(97)00161-4 
De Cock, K. M., Mbori-Ngacha, D., \& Marum, E. (2002). Shadow on the continent: public health and HIV/AIDS in Africa in the 21st century. The Lancet, 360(9326), 67-72. https://doi.org/10.1016/S0140-6736(02)09337-6

Depkes Sul-Sel. (2017). Profil Kesehatan Prov. Sulawesi Selatan Tahun 2017 Profil Kesehatan Prov. Sulawesi Selatan Tahun 2017. Dinas Kesehatan Provinsi Sulawesi Selatan, 1-213.

Estifanos, T. M., Hui, C., Tesfai, A. W., Teklu, M. E., Ghebrehiwet, M. A., Embaye, K. S., \& Andegiorgish, A. K. (2021). Predictors of HIV/AIDS comprehensive knowledge and acceptance attitude towards people living with HIV/AIDS among unmarried young females in Uganda: a cross-sectional study. BMC Women's Health, 21(1), 113.

Green, C.W. (2016). HIV AND TB.

Grulich, A. E., Van Leeuwen, M. T., Falster, M. O., \& Vajdic, C. M. (2007). Incidence of cancers in people with HIV/AIDS compared with immunosuppressed transplant recipients: a meta-analysis. The Lancet, 370(9581), 5967. https://doi.org/10.1016/S0140-6736(07)61050-2

Hamdi, A. C., Wijaya, M., Iskandar, S., \& No, J. R. W. (2016). Pencegahan Penularan HIV/AIDS: Efektivitas Metode KIE “Aku Bangga Aku Tahu (ABAT).”. Bul Penelit Kesehat, 44(4), 245-252.

Indonesia Health Profile. (2019). Indonesia health Profile. In M. boga hardhana, S.Si, Ms. P. farida sibuea, SKM, \& M. winne widiantini, SKM (Eds.), Journal of Chemical Information and Modeling (Vol. 53, Issue 9). www.kemkes.go.id

Juliansyah, E. (2020). Pengaruh Penyuluhan HIV/AIDS terhadap Pengetahuan dan Sikap Siswa SMA Negeri 1 Sepauk Kabupaten Sintang. VISIKES: Jurnal Kesehatan Masyarakat, 19(01).

Kamila, A., \& Ismail, A. (2020). Edukasi HIV/AIDS "Gerakan 1000 Remaja Millenial Peduli Odha"(Gerserha) di MA Al-Mukhtariyah Kabupaten Bandung Barat. Dinamisia: Jurnal Pengabdian Kepada Masyarakat, 4(2), 201208.

Kelley, K. W., Bluthé, R. M., Dantzer, R., Zhou, J. H., Shen, W. H., Johnson, R. W., \& Broussard, S. R. (2003). Cytokine-induced sickness behavior. Brain, behavior, and immunity, 17(1), 112-118. https://doi.org/10.1016/S0889-1591(02)00077-6

Kusnan, A., Eso, A., Asriati, Alifariki, L. O., \& Ruslan. (2019). Pengaruh Penyuluhan HIV/AIDS Terhadap Peningkatan Pengetahuan dan Sikap Siswa Siswi Sekolah. Jurnal Ilmiah Kesehatan (Journal of Health Sciences), $13(1), 88-95$.

Liang, M., Simelane, S., Fillo, G. F., Chalasani, S., Weny, K., Canelos, P. S., ... \& Snow, R. (2019). The state of adolescent sexual and reproductive health. Journal of Adolescent Health,65(6), S3-S15. https://doi.org/10.1016/j.jadohealth.2019.09.015

Makhitha, T. S., \& Botha, P. (2017). Teenagers' sexual activities on school grounds: a need for social work support. Social Work, 53(4), 496-516.

Markolinda, Y., \& Sawirman, .-. (2018). High risk of HIV towards sexual transaction, use of drugs, and lingual symbol of day-pay workers. International Journal of Health Sciences, 2(2), 68-77. https://doi.org/10.29332/ijhs.v2n2.161

Ng, Y. C., \& Caires, A. (2016). The health promotion model in HIV care. Aquichan, 16(4), 418-429.

Notoatmodjo, S. (2010). Promosi kesehatan.

Nubed, C. K., \& Akoachere, J. F. T. K. (2016). Knowledge, attitudes and practices regarding HIV/AIDS among senior secondary school students in Fako Division, South West Region, Cameroon. BMC public health, 16(1), 110.

Porges, S. W. (2003). The polyvagal theory: Phylogenetic contributions to social behavior. Physiology \& behavior, 79(3), 503-513. https://doi.org/10.1016/S0031-9384(03)00156-2

Psacharopoulos, G. (1994). Returns to investment in education: A global update. World development, 22(9), 13251343. https://doi.org/10.1016/0305-750X(94)90007-8

Rahmawati, R. (2020). Edukasi Remaja Putri tentang Ancaman HIV AIDS. Jurnal Abmas Negeri, 1(1), 6-10.

Robinson, P. B., \& Sexton, E. A. (1994). The effect of education and experience on self-employment success. Journal of business Venturing, 9(2), 141-156. https://doi.org/10.1016/0883-9026(94)90006-X

Sambono, M. M. (2013). Studi Perilaku Siswa SMA Ronevan Tual Terhadap Pencegahan HIV dan AIDS di Kelurahan Dullah Selatan Kota Tual. Media Kesehatan Masyarakat Indonesia, 9(1), 1-6.

Sarada, V., \& Mallikarjuna, T. (2018). Socio-economic and psychological problems of third gender people living with HIV/AIDS: A study in A.P. International Journal of Health \& Medical Sciences, 1(1), 10-17. https://doi.org/10.31295/ijhms.v1n1.34

Satriawibawa, I. W. E., Wati, K. D. K., \& Widiastari, A. A. (2018). Penyuluhan efektif meningkatkan pengetahuan tentang HIV/AIDS pada remaja siswa sekolah menengah atas. Journal of The Indonesian Medical Association, 68(2), 65-71. 
Setiawan, D., \& Prasetyo, H. (2015). Metodologi penelitian kesehatan untuk mahasiswa kesehatan. Yogyakarta: Graha Ilmu.

Sudiarto, S., Niswah, F. Z., Pranoto, R. E. P., Hanifah, I., Enggardini, A. A., Masruroh, Z., \& Muhammad, H. N. A. (2019). Optimalisasi Pendidikan Kesehatan Kepada Remaja Melalui Aplikasi Android Profoteen. Jurnal Kepemimpinan dan Manajemen Keperawatan, 2(2), 74-79.

Syed, I. A., Sulaiman, S. A. S., Hassali, M. A., \& Lee, C. K. (2013). HIV/AIDS treatment and health related quality of life: Importance of knowing patients' perspective. HIV \& AIDS Review, 12(1), 26-27. https://doi.org/10.1016/j.hivar.2013.02.003

Tarkang, E. E., Lutala, P. M., \& Dzah, S. M. (2019). Knowledge, attitudes and practices regarding HIV/AIDS among senior high school students in Sekondi-Takoradi metropolis, Ghana. African Journal of Primary Health Care and Family Medicine, 11(1), 1-11.

UNAIDS. (2019). Joint United Nations Programme on HIV/AIDS.

UNICEF. (2006). Adolescent Development: Perspectives and Frameworks A summary of adolescent needs, an analysis of the various program approaches, and general recommendations for adolescent programming. Adolescent Development And Participation Unit Programme Division.

Yani, A. (2018). Utilization of Technology in the Health of Community Health. PROMOTIF: Jurnal Kesehatan Masyarakat, 8(1), 97-103.

Zimmer-Gembeck, M. J., Alexander, T., \& Nystrom, R. J. (1997). Adolescents report their need for and use of health care services. Journal of Adolescent Health, 21(6), 388-399. https://doi.org/10.1016/S1054-139X(97)00167-5 